\title{
Perioperative latex hypersensitivity reactions: an integrative literature review
}

\author{
Aline Nair Biaggio Mota ${ }^{1}$ \\ Ruth Natalia Teresa Turrini²
}

This article characterizes hypersensitivity reactions during anesthetic-surgical procedures. This integrative literature review was conducted in the LILACS, CINAHL, COCHRANE and MEDLINE databases including papers published from 1966 to September 2011. A total of 17 case reports, two prevalence studies and one cohort study were identified. Latex reactions were mainly type III and the primary source of intraoperative reaction was latex gloves. The average time for clinical manifestation was 59.8 minutes after anesthetic induction; $44.4 \%$ of patients reported a reaction to latex at the pre-anesthetic evaluation. It was determined that the history of allergic reactions to latex obtained in the pre-anesthetic evaluation does not ensure the safety of patients if the staff is inattentive to the severity of the issue. There is also a tendency to initially attribute the anaphylactic event to the anesthetic drugs.

Descriptors: Nursing; Latex Hypersensitivity; Perioperative Care; Review.

${ }^{1}$ Undergraduate student, Escola de Enfermagem, Universidade de São Paulo, Brazil.

2 PhD, Professor, Escola de Enfermagem, Universidade de São Paulo, Brazil. 


\section{Hipersensibilidade ao látex no período perioperatório: revisão integrativa da literatura}

Este estudo teve por objetivo caracterizar as reações de hipersensibilidade ao látex em procedimentos anestésico-cirúrgicos. Foi realizada revisão integrativa da literatura nas bases LILACS, CINAHL, COCHRANE e MEDLINE, com seleção de artigos publicados em periódicos indexados de 1966 a setembro de 2011. Foram identificados 17 relatos de caso, dois estudos de prevalência e um de coorte. As reações ao látex foram majoritariamente do tipo III, e a principal fonte desencadeadora de reações no intraoperatório foram as luvas de látex; o tempo médio para manifestação da reação foi de 59,8 minutos após a indução anestésica; 44,4\% dos pacientes relataram episódio de reação ao látex na avaliação pré-anestésica. Identificou-se que a história de episódios de reações a materiais de borracha, ou alimentos, na avaliação pré-anestésica não garante a segurança dos pacientes, se o profissional não estiver alerta à gravidade do problema; no caso de ocorrência de um evento anafilactoide, os profissionais tendem a suspeitar inicialmente dos medicamentos anestésicos.

Descritores: Enfermagem; Hipersensibilidade ao Látex; Assistência Perioperatória; Revisão.

\section{Hipersensibilidad al latex en el peri-operatório: una revisión integradora de la literatura}

Este estudio tuvo como objetivo caracterizar las reacciones de hipersensibilidad al látex en la anestesia. Ha sido realizada una revisión integradora de la literatura en LILACS, CINAHL, COCHRANE y MEDLINE, con una selección de artículos publicados en periódicos indexados de 1966 hasta septiembre 2011. Fueron identificados 17 casos clínicos, 2 estudios de prevalencia y 1 de la cohorte. Las reacciones al látex fueron en su mayoría del tipo III y la principal fuente de reacción intra-operatoria fue el contacto con los guantes de látex. El tiempo medio hasta la aparición de respuesta fue de 59.8 minutos después de la inducción, 44,4\% de los pacientes informaron una reacción al látex en el periodo pre-anestésico. La historia de reacciones alérgicas al látex en el periodo preanestésico no garantiza la seguridad de los pacientes si el profesional no está atento a la gravedad del problema. Al principio, se tiende a atribuir que el efecto de la anafilaxia se debe a los medicamentos anestésicos.

Descriptores: Enfermería; Hipersensibilidad al Látex; Atención Perioperativa; Revisión.

\section{Introduction}

Latex gloves have been used since the 19 th century to protect patients from the transmission of infectiouscontagious diseases. By the end of the 1980s, however, their use grew in frequency and importance mainly due to the emergence of the HIV virus, and an increase in the production of inadequate gloves was observed. These were produced with an excess of powder and residual proteins - agents that typically cause allergenic reactions in latex-sensitive individuals - unleashing a sensitization process $^{(1-2)}$. Thereafter, the first intraoperative cases of anaphylaxis were reported, which demanded that attention be paid by health workers to the seriousness of the problem ${ }^{(3)}$.

Natural Rubber Latex (NRL) is extracted from the sap of the Hevea brasiliensis, also known as the rubber tree. Its original form is a milky liquid composed of $60 \%$ water, $35 \%$ rubber and $5 \%$ of other substances, such as carbohydrates and minerals. Approximately 250 different proteins are found in NRL, but only $5 \%$ of them were identified as inducing hypersensitivity(4). 
Approximately $50 \%$ of medical devices contain latex. Both residual proteins and chemical compounds used in its production are associated with the development of reactions ${ }^{(5)}$. The terminology used to discriminate the three potential reactions is confusing, namely: irritant contact dermatitis, allergic contact dermatitis, and type I hypersensitivity or immediate hypersensitivity.

Irritant contact dermatitis is a non-allergic skin and inflammatory reaction arising from chemical compounds or the products' mechanical action. Its response occurs in minutes or hours and is characterized by dry skin, cracking, redness, burning and itching ${ }^{(6)}$.

Allergic contact dermatitis or type IV delayed hypersensitivity is an allergic response mediated by lymphocytes $\mathrm{T}$ and generally located on the site of contact with the latex containing material(5). It is also caused by the chemical substances added during the manufacture of latex; its clinical signs usually emerge 24 hours after exposure, including itching, erythema, blisters, and cracks similar to the irritant dermatitis(6).

Type I hypersensitivity, or mediated by IgE cells, is a systemic response to residual proteins and, therefore, the only reaction classified as one allergic to latex. Studies indicate that type I reactions affect approximately $0.8 \%$ to $6.5 \%$ of the general population. A total of 1,200 cases were recorded in 1997 alone, 13 of which were fatal(7). Susceptibility in the risk groups is associated with the intensity and frequency with which an individual stays in contact with the latex: it affects $28 \%$ to $73 \%$ of individuals with myelodysplasia( ${ }^{(8)}$ and its risk increases $50 \%$ among patients with urogenital malformations ${ }^{(9)}$.

One of the most frequent forms of becoming sensitive to latex occurs by the ingestion of certain foods, especially fruits (i.e. banana, kiwi and avocado) due to the cross reaction among the allergic compounds of these fruits common to latex ${ }^{(10-11)}$.

There are many challenges to be overcome in the surgical environment where there is a high risk of exposure. The primary avenue of systemic exposure to latex is cutaneous, through tourniquets, electrodes, gloves, anesthetic masks, and bandages, generally leading to the development of rashes and angioneurotic edema(12). However, the most severe reactions result from invasive procedures in which NRL comes into contact with the endothelium, mucosae (especially oral and vaginal mucosa, and mucosa of the urethra and rectum), internal organs and tissue ${ }^{(8)}$.

Inhaling residual proteins may also cause reactions, generally bronchospasms, rhino conjunctivitis, asthma, or airway edema. These airborne allergens are released during the anesthetic process through mechanical ventilation equipment and even by simply handling NRLcontaining products ${ }^{(13)}$

Even though the possibility of patients presenting hypersensitivity to latex in the intraoperative period is acknowledged, patients are not frequently asked during the preoperative assessment, a time when prior allergy history is verified, whether they have had reactions to rubber and patients do not always have the initiative to mention dermatitis associated with the use of domestic gloves $^{(5)}$. Such a fact motivated us to search the literature addressing manifestations of allergic reactions to latex in the intraoperative period.

The Evidence-Based Practice (EBP) approach, which connects research and care practice, was used in this study. When facing a problem, EBP enables one to seek and critically evaluate the best and most recent evidence available, implementing it into practice and analyzing the results. Therefore, this approach grounds care delivery in scientific knowledge, enabling better quality care coupled with more effective costs ${ }^{(14)}$.

For that, the use of scientific and systematic literature review methods to search, evaluate, and synthesize data, are required. This is an integrative review, which enables the synthesis and analysis of scientific knowledge already produced regarding the studied subject(15). This type of study compiles data from different research designs ${ }^{(16)}$, including clinical papers and reviews ${ }^{(17)}$.

Given the previous discussion, this study sought scientific evidence related to the hypersensitivity reactions observed in anesthetic surgical procedures, according to factors related to the patients and types of surgery.

\section{Methods}

This integrative review consisted of the following steps: developing the guiding question, searching the literature, categorizing the studies found, evaluating those included in the review, discussion and interpretation of results, and synthesis of knowledge found in the analyzed papers ${ }^{(16)}$.

The guiding question was: "What are the reactions due to hypersensitivity to latex frequently observed in anesthetic-surgical procedures?"

The study period involved all the studies identified in the electronic search in the databases LILACS, CINAHL, COCHRANE and MEDLINE. Since the oldest 
database hosts papers beginning in 1966, we searched the period from 1996 to 2011.

We used the search PICO methodology(18), in which $\mathrm{P}$ stands for Patient, I for Intervention, $\mathrm{C}$ for Comparison group and $\mathrm{O}$ for Outcomes. The search structure with the health descriptors was organized as: P (surgery OR anesthetics), I (latex OR rubber OR surgical gloves), O (latex hypersensitivity OR dermatitis OR dermatitis contact OR hypersensitivity). We used the same structure with the Boolean term AND to make a connection between the search boxes in the databases that did not interface with this strategy.

Allergy latex and type I hypersensitivity, or mediated by IgE cells, were considered to be a systemic response to residual proteins developed within a few minutes after contact or handling NRL -containing material(5).

The following inclusion criteria were adopted for the papers: articles that focused on the surgical and anesthetic complications related to latex hypersensitivity in individuals older than 18 years.

The exclusion criteria were: studies addressing the latex allergic process mechanism of action, clinical and obstetric cases of latex allergies, studies with children, experimental studies with animals, laboratory tests, protocols, preventive measures, allergies to condoms and medications, studies addressing anaphylaxis in the dental field and theoretical trials.

A guiding instrument developed by the authors was used to guide summarization of information with the following variables: year of publication, type of study, objective, study period, place of publication, population, age, gender, type of surgery, characteristic of reaction, prior history of allergies, results and conclusions.

Hypersensitivity reactions were characterized according to the Laxenaire Classification(19), which identifies four categories of reaction according to severity and symptomatology, namely: type I, which subdivides into: Ia (localized erythema) and Ib (erythema, hives, face or mucosa edema); type II that includes the same symptoms in skin and mucosae from IB reactions but also includes nausea, cough, dyspnea, tachycardia above $30 \%$ or hypotension above $30 \%$; type III, which in addition to the same symptoms of skin and mucosae, includes nausea, vomiting, diarrhea, bronchospasm, cyanosis, or shock; type IV, considered the most severe, including the same symptoms of skin and mucosae in addition to gastrointestinal reaction type III plus respiratory or cardiac arrest.
The studies found were classified according to the level of evidence using the Oxford Centre for Evidence-Based Medicine (CEBM) ${ }^{(20)}$, which are: $1 \mathrm{~A}$ level - systematic review (with homogeneity) of controlled and randomized clinical trials; $1 \mathrm{~B}$ level controlled and randomized clinical trial with a narrow confidence interval; $1 \mathrm{C}$ level - therapeutic outcomes all-or-nothing"; 2A level - systematic reviews of cohort studies; 2B level - cohort studies (including lower quality randomized clinical trials); 2C level observation of therapeutic results, ecological studies; $3 \mathrm{~A}$ level - systematic review (with homogeneity) of case control studies; 3B level - case control study; 4 level case reports (including cohort and case control of lower quality) and 5 level - opinion deprived from critical evaluation or based on basic material (physiological or animal studies).

\section{Results}

A total of 836 studies were initially found, and after selection and analysis through the application of inclusion and exclusion criteria, 20 papers were chosen. Most of these $(n=12)$ were conducted in Europe, followed by the United States $(n=7)$, and Oceania $(n=1)$. Studies were mainly published in the 1990s $(n=19)$, and case reports predominated $(n=17)$ when compared to epidemiological studies $(n=3)$, while the latter included two prevalence studies and one cohort study. According to the classification of CEBM levels of evidence, the studies presented a level of evidence 4. Following, we present a synthesis of case reports and epidemiological studies.

\section{Synthesis of case reports}

A total of 18 cases were reported in 17 studies (Figure 1). The patients involved were mainly women $(82.3 \%)$ and the average age was 40.2 years old (from 19 to 63 years old). The surgical procedures involved in the reported cases included five (29.4\%) surgeries in the gastrointestinal tract (E4, E6, E9, E10, E16), three $(17.6 \%)$ orthopedic surgeries (E11, E13, E14), three $(17.6 \%)$ plastic surgeries (E1, E2, E3), two $(11.8 \%)$ surgeries for tumor resection (E5, E12), one $(5.9 \%)$ renal surgery (E15), one $(5.9 \%)$ urological (E8), one (5.9\%) vascular (E7), and one (5.9\%) organ transplantation (E17). 


\begin{tabular}{|c|c|c|c|}
\hline Author (Study) & Year & Prior history of allergy & Result of the test for latex allergy \\
\hline Zenarola (E1) & 1989 & Latex gloves & Positive provocation tests \\
\hline Sleth, Legroux (E2) & 1990 & Avocado, latex gloves, balloons & 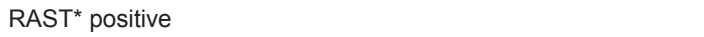 \\
\hline Lesavoy et al. (E3) & 1994 & - & Positive skin test \\
\hline Spears et al (E4) & 1995 & - & $\mathrm{RAST}^{*}$ positive \\
\hline Menéndez et al(E5) & 1995 & Paints, gloves and balloons & 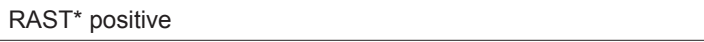 \\
\hline Ballantyne et al. (E6) & 1995 & - & Positive skin test; RAST positive \\
\hline Gosgnach et al. (E7) & 1995 & Shellfish & Positive basophils degranulation; RAST* positive \\
\hline Pollard, Layon (E8) & 1996 & - & RAST* $^{*}$ positive \\
\hline Fisher (E9) & 1997 & - & $\begin{array}{l}\text { Patient A: elevated tryptase; histamine normal; positive skin test. } \\
\text { Patient B: elevated tryptase; histamine normal; positive skin test. }\end{array}$ \\
\hline Gutiérrez et al. (E10) & 1997 & - & RAST $^{*}$ positive \\
\hline Chomel-Cosimo et al. (E11) & 1999 & - & $\begin{array}{l}\text { Tests were not performed (there was not prior suspicion of latex } \\
\text { allergy) }\end{array}$ \\
\hline Kashima et al. (E12) & 2001 & - & 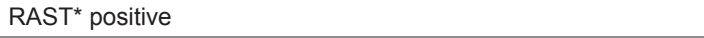 \\
\hline Pirat et al. (E13) & 2003 & Citric fruits & $\begin{array}{l}\text { Elevated tryptase and histamine; RAST * positive; positive skin } \\
\text { test for natural latex extract; positive basophils degranulation to } \\
\text { avocado. }\end{array}$ \\
\hline Hebl, Hall, Sprung (E14) & 2004 & $\begin{array}{l}\text { Ambrosia-American, } \\
\text { Polyvinylpyrrolidone lodine }\end{array}$ & Elevated tryptase; positive skin test \\
\hline Lenchner, Ditto (E15) & 2005 & - & $\begin{array}{l}\text { Positive skin test to latex sap and the fruits: fresh plum, papaya, } \\
\text { tomatoes, and almonds. }\end{array}$ \\
\hline $\begin{array}{l}\text { Sánchez-Ródenas, Sánchez- } \\
\text { Ortega (E16) }\end{array}$ & 2005 & - & $\begin{array}{l}\text { Elevated tryptase and histamine; RAST* positive; Positive skin } \\
\text { test for latex, kiwi and nuts. }\end{array}$ \\
\hline Jacqmarcq, Karila, Carli (E17) & 2005 & Known hypersensitivity to latex & $\begin{array}{l}\text { Elevated tryptase and histamine; RAST* positive; Positive skin } \\
\text { tests. }\end{array}$ \\
\hline
\end{tabular}

*Radioallergosorbent Test - blooding test (in-vitro) to detect specific IgE antibodies

Figure 1 - Synthesis of care reports identified in the integrative literature review from 1996 to September 2011

In relation to prior history of allergies: eight $(44.4 \%)$ of the patients reported some prior event of reaction at the time of the pre-anesthetic consultation (E1, E2, E5, E7, E11, E13, E14, E17). The reported sources of allergic reactions included rubber gloves (E1, E2, E5), balloons (E2, E5), citric fruits (E13), avocado (E2), American ambrosia (E14), and shellfish (E7). The source was not reported in one of the studies (E11), and in another study (E17), the patient had already been diagnosed with a latex allergy through a laboratory test and underwent a latex free surgery, but the reaction occurred due to exposure to the transplanted organ.

Among the patients who did not report allergic antecedents, seven (38.9\%) recalled, after a diagnosis of latex hypersensitivity was obtained in the postoperative, some type of reaction such as an allergy to fruits, among them avocado, banana, melon, nuts (E10, E16), balloons (E3, E10, E12, E16), rubber gloves (E9, E10, E12, E16) and a reaction after a gynecological exam, presumably related to the physician's gloves (E6).

Six sources were identified as triggering intraoperative (46.2\%) episodes of hypersensitivity due to the latex gloves used by the surgeons (E2, E3, E8, E15, E13, E16), followed by two $(15.4 \%)$ reactions to central catheters, one venous (E12) and one pulmonary artery catheter (E7) two (15.4\%) delayed vesical catheterization (E4), one (7.7\%) from monitoring electrodes (E1), one (7.7\%) endotracheal tube (E1) and one $(7.7 \%)$ due to the manipulation of a kidney with latex gloves during harvesting of transplantation organs (E17).

The initial suspicions in seven $(41.1 \%)$ studies were attributed to the medication used such as the anesthetic: isoflurane (E10, E11), rocuronium (E15), lidocaine (E7) and non-specified anesthetics (E17) and other medications used such as heparin (E7), neostigmine (E9), cefazolin (E4), ciprofloxacin (E15), and polyvinylpyrrolidone-iodine (E7). In addition to these, in one of the cases, the patient's reaction was attributed to a potential malignant hyperthermia (E3).

Twenty-one anaphylactoid reactions were observed in 18 patients due to new attempts to perform the procedure; the intensity of reactions worsened in two of them (E1, E7). According to the severity score of anaphylactoid reactions ${ }^{(19)}$, two $(9.5 \%)$ were reactions of type Ib (E1, E3), seven (33.3\%) type II (E2, E7, E9 - two events, E12, E14, E15) and 12 (57.2\%) type III (E1, E4 - two events, E5, E6, E7, E8, E10, E11, E13, E16, E17). Among the patients who presented level III reactions (11), six (54.5\%) presented prior histories of allergies (E1, E5, E7, E11, E13, E17) recorded in their pre-anesthetic evaluations. 
Considering the type of procedure, type III reactions were distributed as follows: five (41.7\%) occurred during surgical procedures in the gastrointestinal tract (E4 two events, E6, E10, E16), two (16.7\%) in orthopedic procedures $(E 11, E 13)$, one $(8.3 \%)$ in vascular surgery $(E 7)$, one $(8.3 \%)$ in plastic surgery $(E 1)$, one $(8.3 \%)$ in a urological procedure (E8), one in $(8.3 \%)$ organ transplantation (E17) and one (8.3\%) during a tumor resection (E5).

The time took for signs and symptoms of hypersensitivity to manifest varied according to the criterion used by the authors. Some considered the time from the beginning of the surgery and others from the anesthetic induction. The average time among the studies $(n=8)$ reporting time of manifestation of signs and symptoms after anesthetics was 59.8 minutes $(S D= \pm 45.8 \mathrm{~min})$, with a median of 45 minutes (from 20 to 160 minutes). Only one study (E7) reported time after the beginning of the surgery (60 minutes); another mentioned only a few minutes after the incision (E15); and in another study, the reaction occurred before the beginning of the procedure (E4).

The procedure was interrupted in six (33.3\%) cases because of the reaction (E1, E4, E6, E7, E12, E15,). In the remaining, the anaphylactoid reaction was controlled during the surgery up to the end of the reaction.

Postoperative tests were performed to investigate the anaphylactoid reaction in $15(83.3 \%)$ patients. There was a predominance of specific IgE dosage (RAST) for latex $(55.5 \%)$, followed by cutaneous testing for the anesthetics used and NRL (Figure 2). The provocation test was conducted in study E1, which consists of a controlled administration of a substance for the diagnosis of hypersensitivity reactions, considering the use of an intubation tube and cardiac monitoring electrodes.

\begin{tabular}{|l|l|c|c|}
\hline \multicolumn{1}{|c|}{ Test } & \multicolumn{1}{|c|}{ Studies } & \multicolumn{1}{c|}{$\mathbf{N}(\%)$} & $\begin{array}{c}\text { N (\% } \\
\text { positivity) }\end{array}$ \\
\hline $\begin{array}{l}\text { Latex-specific IgE } \\
\text { determinations }\end{array}$ & $\begin{array}{l}\text { E2, E4, E7, E8, E10, } \\
\text { E12, E13, E16, E17, } \\
\text { E20 }\end{array}$ & $10(55.5)$ & $10(100)$ \\
\hline Anesthetic skin test & $\begin{array}{l}\text { E6, E7, E9*, E11, E14, } \\
\text { E16, E17, }\end{array}$ & $8(44.4)$ & $-(-)$ \\
\hline Skin test for latex & $\begin{array}{l}\text { E3, E6, E13, E14, E15, } \\
\text { E16, E17 }\end{array}$ & $7(38.8)$ & $6(85.7)$ \\
\hline Tryptase & $\begin{array}{l}\text { E9*, E13, E14, E16, } \\
\text { E17 }\end{array}$ & $6(33.3)$ & $6(100)$ \\
\hline
\end{tabular}

(continue...)

\begin{tabular}{|l|l|c|c|}
\hline \multicolumn{1}{|c|}{ Test } & \multicolumn{1}{|c|}{ Studies } & \multicolumn{1}{c|}{ N (\%) } & $\begin{array}{c}\text { N (\% } \\
\text { positivity) }\end{array}$ \\
\hline Histamine & $\begin{array}{l}\text { E9*, E13, E14, E16, } \\
\text { E17 }\end{array}$ & $6(33.3)$ & $4(66.6)$ \\
\hline Skin test for fruits & E10, E13, E15, E16 & $4(22.2)$ & $3(75)$ \\
\hline Basophils & E7 & $1(5.6)$ & $1(100)$ \\
\hline Total lgE levels & E10 & $1(5.6)$ & $1(100)$ \\
\hline Provocation test & E1 & $1(5.6)$ & $1(100)$ \\
\hline
\end{tabular}

* 2 patients

Figure 2 - Distribution of the number of patients according to the type of test used to identify anaphylactoid reactions in the postoperative.

The patient from study E5 was not included in the list of tests because he had already presented an anaphylactoid reaction before the surgery after coming into contact with the nursing professional's glove and presented a positive RAST to latex, determining that the surgical procedure should be performed in a latex free environment.

Four reports (E3, E4, E5, E8) defended the prophylactic use of antihistaminic drugs and/or corticoids for those with a history of pre-anesthetics allergies. The patients from two of the studies (E4, E5) were medicated prior to their procedures and the environment was free of latex. In another two studies (E16, E12) however, such practices were not adopted.

\section{Synthesis of epidemiological studies}

Figure 3 presents a synthesis of epidemiological studies. The average time of observation for data collection in these studies was 15 months, ranging from 6 to 24 months (E18, E20). Two studies addressed patients according to surgical specialty: 325 patients were awaiting urological procedures and 204 patients were from the Ear, Throat and Nose (ETN) Department in study E18; while 206 from the abdominal surgery department were included in study E19. The studies' main objective was to evaluate the prevalence of latex hypersensitivity.

A total of 39 patients with hypersensitivity reactions or adverse reactions from unknown causes manifested during the anesthetic process were included in study E20. The study evaluated the incidence of these reactions through skin and blood tests for histamine and tryptase. 


\begin{tabular}{|c|c|c|l|l|}
\hline Author (Study) & Year & Type & \multicolumn{1}{|c|}{ Population } & \multicolumn{1}{c|}{ Results } \\
\hline Ruëff et al (E18) & 2001 & Prevalence & -325 patients undergoing urological surgery & $\begin{array}{l}-4.9 \% \text { of test + latex } \\
-7.1 \% \text { positive RAST } \\
-33.2 \% \text { atopic (19.4\% allergic) } \\
-5.6 \% \text { of allergy: history of more than } 10 \text { prior surgeries }\end{array}$ \\
\hline $\begin{array}{c}\text { Hilgert et al } \\
\text { (E19) }\end{array}$ & 2007 & Prevalence & -204 ETN patients & $\begin{array}{l}- \text { ETN: } 20,9 \% \text { allergic to latex (16.0\% men and } 27.0 \% \\
\text { women); } 77.0 \% \text { atopic. } \\
\text { - abdominal surgery: } 11.3 \% \text { allergic to latex (9.7\% men } \\
\text { and } 12.1 \% \text { women), } 68.0 \% \text { atopic. }\end{array}$ \\
\hline $\begin{array}{c}\text { Malinovski et al } \\
\text { (E20) }\end{array}$ & 2008 & Cohort & $\begin{array}{l}-206 \text { patients of abdominal surgery } \\
-39 \text { patients with hypersensitivity or adverse } \\
\text { reactions during the anesthetic process. }\end{array}$ & $\begin{array}{l}-56.4 \% \text { allergic to latex } \\
-38.4 \% \text { IgE mediated reactions. }\end{array}$ \\
\hline
\end{tabular}

Figure 3 - Presentation of epidemiological studies identified in the integrative literature review from 1966 to September 2011

The prevalence of positive skin tests to latex was $4.9 \%$ and specific IgE was $7.1 \%$ in the study E18. Atopy, which is a predisposition of individuals to present a response from the immunological system to common substances and particles, was found in $33.2 \%$ of the patients and $19.4 \%$ of these were allergic. Cases of latex allergies were observed in patients with more than ten prior surgeries (5.6\%).

In study E19, 20.9\% of those allergic to latex were among patients from the Head and Neck (H\&N) department; only $1.0 \%$ had reported a latex allergy, and $77.0 \%$ were atopic. Among those from the abdominal surgery department, $11.3 \%$ were allergic to latex; only $0.5 \%$ reported latex allergy symptoms and $68 \%$ were atopic.

Of the patients who presented some anaphylactoid reaction in the cohort study E20, 22 (56.4\%) were considered latex-sensitive, 15 (38.4\%) were reactions mediated by $\mathrm{IgE}$, and $12(80 \%)$ of these presented augmented histamine levels, while seven (46.6\%) presented augmented levels of tryptase.

\section{Discussion}

Data from the literature indicate that latex is responsible for approximately $22.3 \%$ of the episodes of perioperative anaphylaxis(21). The epidemiological studies $^{(22-23)}$ presented a prevalence of 10 to $20 \%$ depending on the type of the procedure.

The literature reports that patients undergoing urological procedures and/or frequently exposed to latex material are more vulnerable to latex-sensitivity, as are those with spina bifida ${ }^{(8,21-22)}$. This investigation frequently reported cases in gastrointestinal and $\mathrm{H} \& \mathrm{~N}$ surgeries in the epidemiological studies because studies addressing pediatric patients, just those involved with surgeries due to spina bifida, were excluded.
The reactions more frequently occurred among women, which has been attributed to their frequent exposure to latex by the routine use of rubber gloves while performing home chores and the high number of gynecological and obstetrical interventions, which may be even higher in cases of artificial insemination. Studies show that these interventions may account for up to $50 \%$ of intraoperative anaphylaxis ${ }^{(23)}$. According to the literature, abdominal surgeries are the second most frequent surgical procedure involving latex-sensitivity, after gynecological and obstetrical surgeries, and represent approximately $20 \%$ of the cases $^{(24)}$.

Even though nurses and anesthetists checked for allergic antecedents in the preoperative, it was not sufficient to avoid intraoperative hypersensitivity reactions because some patients had reported an anaphylactoid reaction after ingesting certain foods or having contact with rubber material before the surgical procedure.

Latex allergies are linked to allergies to fruits and vegetables due to a likely cross-reactivity between latex antigens and those contained in certain foods or by the presence of polypeptides that have enzymatic functions. The frequency of sensitization ranges from $18.4 \%$ to $32.1 \%$ in patients allergic to latex and there are many foods that trigger it: avocado, banana, kiwi, grapefruit, papaya, chestnuts, nuts, pineapple, melon, fig, passion fruit, tomato, dates, potatoes, and peach(10).

Later hypersensitivity depends on a detailed investigation to identify patients belonging to risk groups. The employment of forms with specific questions may aid the identification of signs and symptoms not deemed significant by patients and which can suggest the need for a more detailed evaluation through laboratory exams whose results can affect decision-making related to surgical conditions. 
The literature reports the use of an algorithm ${ }^{(25)}$ to help decision-making concerning the diagnosis of latex allergy when the patient presents some risk factor or symptomology that suggests a potential contact dermatitis or hives. Initially, the scheme recommends a patch test (it tests chemical substances that may cause a reaction) is initially performed to evaluate the possibility of delayed hypersensitivity and then the RAST test is performed if there is a suspicion of immediate hypersensitivity. In the case of negative or inconclusive results, the scratch test or skin prick test and/or provocation test is performed.

None of the analyzed studies performed the patch test because the objective was to evaluate a reaction that had already occurred and not the possibility of delayed hypersensitivity. But if the algorithm had been used to detect information regarding a prior history of allergic reactions in the pre-anesthetic evaluation, the intraoperative reactions could have been avoided.

Whenever there is a history suggesting an allergy and confirmatory laboratory results, nurses should make sure the surgical procedure is latex free during the entire perioperative period, preferably rescheduling the surgery to the first hour, so that the level of aeroallergens is at the lowest possible. It is also important to warn the entire multidisciplinary staff by hanging alerts on the doors of the patients' rooms and noting on the patients' medical files, and, whenever possible, to perform trolley maintenance using only latex free material for potential emergencies(26). It is also necessary that whenever nurses instruct patients and families, they emphasize that information concerning potential allergies is crucial for the safety of the surgical procedure.

The Association of PeriOperative Registered Nurses (AORN) developed questions to guide nurses in the investigation of potential rubber latex allergies that should be noted in the patient's preoperative evaluation. These questions evaluate whether the patient presented specific signs and symptoms of hypersensitivity, medical diagnosis of any allergic process and allergy to fruits such as banana, avocado, kiwi and nuts. It also proposes the following framework of symptoms that indicate exposure to latex and potential anaphylaxis facilitating early identification: (1) awaken patient watery eyes, generalized itching, shortness of breath, runny nose, wheezing, nausea, vomiting, abdominal cramps, diarrhea, fainting, feeling of impending death; (2) patient under sedation - facial swelling, hives, rash, flushing, bronchospasm, laryngeal edema, hypotension, tachycardia, cardiac arrest ${ }^{(1)}$.
The use of pharmacological prophylaxis through antihistamine drugs and/or corticoids was a controversial issue in the analyzed studies. There is a premedication protocol that includes the use of Diphenhydramine, Cimetidine and Prednisone(27). Other authors(28) argue that in addition to a lack of scientific evidence, the use of these medications prior to a surgical procedure can harm the identification of the first signs of a hypersensitivity reaction.

An important aspect observed in one of the reported cases was the fact that the source of the allergy in the patient previously known for being latex-sensitive was the donated organ. Even though there are no studies addressing the need to use latex free gloves when removing an organ intended for donation, it seems that this case should be considered a sentinel event indicating the need to use latex free gloves.

The identification of allergies to fruits or reactions to latex material and the number of prior surgeries above ten, as observed in some studies, should warn nurses of the need to implement a latex free surgical environment to avoid adverse events in the intraoperative.

\section{Conclusions}

Latex hypersensitivity is an adverse event that can be avoided when the surgical staff is sensitive to the patient's history concerning skin reactions to food and NRL material, number of prior surgeries or complications in prior surgical events. Type II reactions were frequent, which shows the severity of clinical conditions, and the need for interventions to complete the surgery and in some cases, interrupt the surgery.

Even though the selected studies presented a level of evidence considered to be weak, some findings allow us to conclude that the history of allergic reactions to latex in the pre-anesthetic evaluation does not ensure the safety of patients if the staff is not attentive to the problem's severity; there is a tendency to initially attribute the anaphylactoid event to the anesthetics; and, finally, there is a possibility of a latex hypersensitivity reaction in response to the latex gloves used when harvesting transplantation organs.

The surgical staff in the transplantation organ surgery knew the receptor patient was latex-sensitive but the latex free environment was not sufficient to avoid an allergic reaction because they had not considered the donated organ could be "contaminated" by latex proteins. Considering the complexity of transplantation procedures and the risk posed to patients, further studies 
are needed to consider the use of latex free gloves when harvesting organs.

Latex hypersensitivity is an adverse event and could be considered rare, thus, case reports can contribute to the review of actions in the care process. Studies are needed that address: the cost-benefit analysis of confirming latex hypersensitivity through laboratory tests in surgical patients suspected to be latex sensitive; the reason why some professionals do not value reports of reactions when in contact with NRL; or food that triggers these reactions. These investigations could be amenable to the planning of perioperative care and reduce the number of adverse events related to latex.

It is the role of nurses to identify potential risks of latex hypersensitivity in order to anticipate the need to reserve latex free material for the intervention. It would prevent delays in the surgical schedule and give priority to the latex free procedure before NRL material is handled with in the surgical room, possibly causing the dissemination of latex particles in the environment.

\section{References}

1. Yip ES. Accommodating latex allergy concerns in surgical settings. AORN J. 2003;78(4):595-603.

2. Xelegati R, Robazzi MLCC, Marziale MHP, Haas VJ. Riscos ocupacionais químicos identificados por enfermeiros que trabalham em ambiente hospitalar. Rev. Latino-Am. Enferm. 2006;14(2):214-9.

3. Young MA, Meyers M, McCulloch LD, Brown LJ. Latex allergy: A guideline for perioperative nurses. AORN J. 1992;56:488-502.

4. AORN. Perioperative Standards and Recommended Practices. AORN J. 2008:87-102.

5. Baptista FM, Alcântara FB, Glashan RQ. O que o enfermeiro deveria saber a respeito do látex. Nursing. (São Paulo). 1999;2(18):18-22.

6. Canuto DB, Costa DU, Silva LD. Trabalhador de enfermagem alérgico a luva de látex: um estudo sobre outras opções. Rev Enferm UERJ. 2007;15(1):125-9.

7. Bundensen IM. Natural Rubber Latex: a Matter of Concern for Nurses. AORN J. 2008;88(2):197-210.

8. Golas M, Durrance S. AORN Latex Guideline. AORN J. 2004;79(3):653-72.

9. American Academy of Allergy Asthma and Immunology (AAAAI) [Internet]. Milwaukee; c1996-2009. [atualizado em jan 2009; acesso 14 mar 2009]. Disponível em: http://www.aaaai.org/patients/publicedmat/tips/ latexallergy.stm.
10. Marin FA, Peres SPBA, Venturini MC, Francisco RCM, Zuliani A. Alergia ao látex e a frutas em profissionais da área da saúde. Rev Nutr. (Campinas). 2003;16(4):415-21. 11. Weiss SJ, Halsey JF. A nurse with anaphylaxis to stone fruits and latex sensitivity: potential diagnostic difficulties to consider. Ann Allergy Asthma Immunol. 1996;77(6):504-8.

12. Marcer G, Gemignani C, Coco G. Natural latex allergy. Patient management: from clinic to prevention. A review. Med Lav. 2008;99(2):113-7.

13. Floyd PT. Latex allergy update. J PeriAnesth Nurs. 2000;15(1):26-30.

14. Mendes KDS, Silveira RCCP, Galvão CM. Revisão integrativa: método de pesquisa para a incorporação de evidências na saúde e na enfermagem. Texto Contexto Enferm. 2008;17(4):758-64.

15. Ganong LH. Integrative reviews of nursing research. Res Nurs Health. 1987;10(1):1-11.

16. Whittemore $\mathrm{R}, \mathrm{Knafl} \mathrm{K}$. The integrative review: updated methodology. J Adv Nurs. 2005;52(5):546-53.

17. Beyea SC, Nicoll LH. Writing an integrative review. AORN J. 1998;67(4):877-80.

18. Santos CMC, Pimenta CAM, Nobre MRC. The PICO strategy for the research question construction and evidence research. Rev. Latino-Am. Enfermagem. 2007;15(3):508-11.

19. Laxenaire MC, Charpentier C, Feldman L. Grupo de Estudos de Tolerância aos Substitutos Plasmáticos da França. Anaphylactoid reactions to colloid plasma substitutes: frequency, risk factors, mechanisms. A French prospective multicentre inquiry. Ann Fr Anesth Réanim. 1994;13:301-10.

209. Levels of Evidence. Centre for Evidence-based Medicine (CEBM) [Internet]. Oxford: March 2009. [atualizado em 5 jul 2010; acesso 2 ago 2010]. Disponível em: http://www.cebm.net/index.aspx?o=1025.

21. Ozkaya E, Coskun Y, Turkmenoglu Y, Samanci N. Prevalance of latex sensitization and associated risk factors in Turkish children with spina bifida. Pediatr Surg Int. 2010;26:535-8.

22. Bozkurt G, Sackesen C, Civelek E, Kalayci O, Akalan $\mathrm{N}$, Cataltepe $\mathrm{O}$. Latex sensitization and allergy in children with spina bifida in Turkey. Childs Nerv Syst. 2010;26(12):1735-42.

23. Turillazzi E, Greco P, Neri M, Pomara C, Riezzo I, Fineschi V. Anaphylactic latex reaction during anaesthesia: The silent culprit in a fatal case. Forensic Sci Int. 2008;179(1):e5-8. 
24. Lieberman P. Anaphylactic reactions during surgical and medical procedures. J Allergy Clin Immunol. 2002;110(2):s64-s70.

25. Warshaw EM. Latex Allergy. J Am Acad Dermatol. 1998;39(1):1-24.

26. American Society of Anesthesiologists [Internet]. Natural Rubber Latex Allergy: Considerations for Anesthesiologists, 2005. [acesso 10 nov 2010]. Disponivel em: http://ecommerce.asahq.org/ publicationsAndServices/latexallergy.pdf

27. Merguerian PA, Klein RB, Graven MA, Rozycki $A A$. Intraoperative anaphylactic reaction due to latex hypersensitivity. Urology. 1991;38:301-4.

28. Setlock MA, Cotter TP, Rosner D. atex allergy: Failure of prophylaxis to prevent severe reaction. Anesth Analg. 1993; 76:650-2. 